THE UNIVERSITY of EDINBURGH

Edinburgh Law School

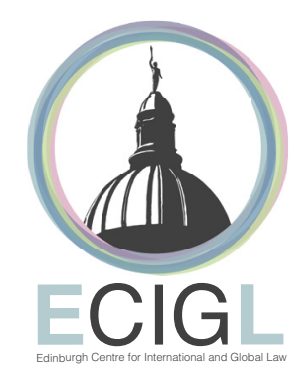

What do we mean when we talk about international energy law?

Volker Roeben and Gokce Mete

Edinburgh Centre for International and Global Law Working Paper Series

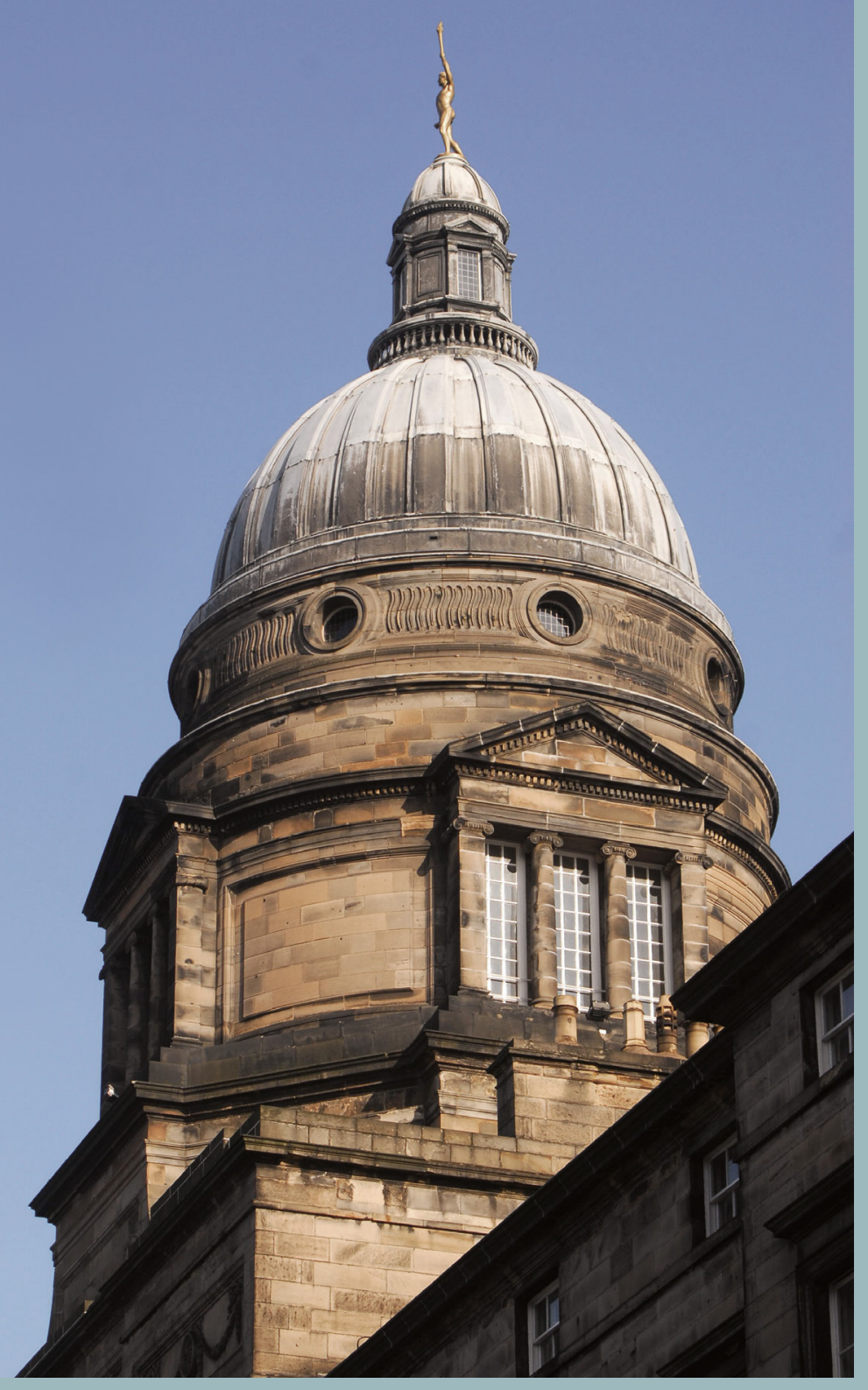




\title{
What do we mean when we talk about international energy law?
}

\author{
Volker Roeben and Gokce Mete
}

\section{Introduction}

In the literature it remains hotly debated whether international energy law as a distinct subjectmatter of public international law exists and what it comprises. The starting point is that energy has long been considered to fall primarily within the domain of domestic law. That is reflected in principles such as the permanent sovereignty over natural resources, which reserves disposition to the territorial sovereign over their upstream energy resources. Yet the climate action driven transition to a low-carbon economy has cast a novel perspective on the dynamic international law relating to energy in all its forms. At this juncture, the purpose of this paper is to advance conceptual and semantic clarity about what international lawyers mean when they talk about international energy law. The paper is hence analytic, rather than normative or legallyreconstructive. It proposes a distinction between a 'thin' and a 'thick' concept of international law relating to energy. The 'thin', structural concept refers to the bundle of international rules that really belong to other sectors but touch on aspects of energy. This is arguably what astute observers have in mind when stating that an international energy law does not exist, instead there are general principles of international law that apply to the energy sector. ${ }^{1}$ We term this 'thin' concept, the 'international law on energy'.

By contrast, the 'thick' concept is evaluative. It evaluates whether there is a distinct body of international law dedicated to the energy sector. The paper unpacks this thick concept by making three arguments. It argues that access to sustainable and affordable energy for all sits at the heart of this body of international law as a 'meta norm'; that this meta-norm determines the characteristics of an international regulatory approach to the energy value chain; and that it leads several other established regimes of international law to realign themselves with it. These three arguments are interrelated; they set the boundaries of that distinct body of international law. We term this thick concept 'international law of energy'. We claim that international lawyers ought to refer to this international law of energy in order to meaningfully speak about the current and future international regulation of the field of energy.

\footnotetext{
${ }^{1}$ Catherine Redgwell, International Regulation of Energy Activities in Energy Law in Europe: National, EU and International Regulation, Martha Roggenkamp et al eds. (3 ${ }^{\text {rd }}$ ed. OUP 2016), 14; Danae Azeria, Treaties on Transit of Energy via Pipelines and Countermeasures (CUP, 2016) (applying the general law of treaties and state responsibility). This paper does not deny the applicability of general international law. It rather is making the point that the international law of energy is specific and that this specificity determines its relation with other international law.
} 
First, the international law of energy rests on a meta-norm that mandates a transition to a lowcarbon global economy to provide all with access to sustainable and affordable energy. The metanorm has been formalised, in 2015, by the international community of states in the universally accepted Sustainable Development Goals (SDGs) 7 and 13 of the UN Agenda 2030. SDG 7 relates to ensuring access to clean and affordable for all, and SDG 13 relates to international climate action. ${ }^{2}$ To this end, it promotes renewable energy sources, transmission through trans-boundary grids, and efficiency in consumption. Agenda 2030 defines the pathway of future legal concretisation of both SDGs. The 2015 Paris Agreement on Climate Change (the Paris Agreement $)^{3}$ provides concretisation through universally binding international law of these SDGs for the energy sector that accounts for more than $70 \%$ of worldwide carbon emissions. This prioritisation translates into accountability and parameters and benchmarks for states parties on their energy policies.

Second, this meta-norm now underpins a single approach to legal change in international law. This approach is regulatory. Regulatory is used here in the sense that SDGs 7, 13 and the Paris Agreement formulate goals on the future provision of energy that are to be achieved within a certain timeframe by all states acting individually and jointly. The regulatory change deploys institutionalised rule-making on energy throughout the value-cycle, from generation, through transportation to consumption (end-uses). In so doing, the change tests and indeed pushes the boundaries of established doctrines of international law, such as institutional oversight, dynamic treaty development and implementation, the regulation of private conduct, and the concern for social justice and the welfare of people.

Third, the extant international law that relates to energy is marked by plurality. There is some significant energy-specific international law. However, the mass originates in regimes across all sectors of international law, reflecting the horizontal nature of energy. The emergence of the metanorm has profound consequences for this plural law. Each regime self-aligns with the meta-norm to advance its implementation by using the instruments available under each regime. There is clear evidence of such self-alignment under the 1994 Energy Charter Treaty (ECT) ${ }^{4}$ that will be documented extensively throughout this paper. But the trend comprises most, if not all energyrelevant regimes, such as the law of natural resources, trade law, investment law, environmental law, or the law the sea, albeit to different degrees in each regime as will be demonstrated.

\footnotetext{
${ }^{2}$ More information on the UN Sustainable Development Goals is available at: https://www.un.org/sustainabledevelopment/sustainable-development-goals/.

${ }^{3}$ Paris Agreement to the United Nations Framework Convention on Climate Change 2015, Doc. FCCC/. CP/2015/10/Add.1 ('Paris Agreement'). The Paris Agreement was adopted on 12 December 2015 at the twenty-first session of the Conference of the Parties to the United Nations Framework Convention on Climate Change held in Paris from 30 November to 13 December 2015. More information is available via: https://unfccc.int/process-andmeetings/the-paris-agreement/the-paris-agreement.

${ }^{4} 2080$ UNTS 95. The Energy Charter Treaty (ECT) and its Protocol on Energy Efficiency and Related Environmental Aspects (ECT) cover energy investments, trade, freedom of energy transit, energy efficiency, and resolution of state-to-state or investor-to-state disputes. More information on the ECT is available at: www.energycharter.org.
} 
The paper concludes that it is meaningful to speak about the international law of energy grounded in a meta-norm directing the development of a dedicated body of international law for energy. This international is a means with which the international community of states delivers the transition to a different global energy system, in a universally binding, effective and formally-rational manner. In the discourse of international lawyers, this thick concept ought to replace an outdated, thinner concept of an international law on energy.

\section{A universal meta-norm for energy}

At the heart of the international law of energy is a universally accepted meta-norm. This section first discusses the concept of a meta-norm and argues that it has the capacity to direct choices on the development of international law (1). It then demonstrates the role of the SDGs (2) and of the Paris Agreement (3) in jointly shaping a meta-norm for the international law of energy.

\section{The concept of meta-norm}

The concept of a meta-norm originates in the study of collective action, in particular of social rules for actors in complex governance schemes. ${ }^{5}$ In this account, a meta-norm embodies the value judgments that those actors refer to when making choices in developing the scheme, and which explain and justify these choices. A meta-norm hence is not prescriptive (ontological) per se. It may and often will be first formalised in policy-documents. For a universal meta-norm, a legitimate formalisation would be in a UN General Assembly resolution reflecting the outcome of a universally attended policy-making conference of states.

Energy is subject to such a complex governance scheme. It is complex on both substantive and organizational grounds. Substantively, this governance scheme means making trade-offs between competing energy-internal goals, expressed in the so-called energy trilemma of sustainability, security of supply, and affordability. It also means choosing between energy-internal goals and energy-external values and rationales that underpin all those sectors of international law that also apply to energy, ranging from trade to environmental protection. Organizationally, energy governance is decentralized, ensured by the $\mathrm{UN}$, a range of specialized international organisations, and increasingly actively by regional integration organisations, in particular the European Union, as well as each sovereign state. This governance scheme is based on rules being adopted on the international, the regional and the national level. A single meta-norm directs actors in making policy and legal choices, on each of these levels, with the international level being the focus of this paper.

\section{SDG 7 and 13 for energy and the 2030 Agenda}

A meta-norm for energy has been now been formalized in the 2030 Agenda of the United Nations that was adopted by the General Assembly in 2015 as the outcome of an inclusive drafting process.

\footnotetext{
${ }^{5}$ See Kooiman and Jentoft, 'Meta-Governance: Values, norms and principles, and the making of hard choices', (2007) 87 Public Administration 818.
} 
It contains the Sustainable Development Goals. The SGDs $7^{6}$ and $13^{7}$ in their combination provide this first formalisation of a novel meta-norm for energy. SDG 7 aims to ensure access to affordable, reliable, sustainable and modern energy for all and SDG 13 aims for urgent action to combat climate change and its impacts. It covers the entire value-chain of energy, from generation through transportation/transmission, to consumption and end-use. It determines that the SGDs are objectives for those actors that are to be achieved over a fifteen-year period and that progress against them can and will be measured. It hence ensures that there is a determined objective that defines a desirable future state of affairs for global energy that is different from the status quo. These SDGs are set within Agenda 2030. Agenda 2030, adopted by the UN GA in 2015, mandates all states, developed and developing, and the international organisations to work towards achieving them. It makes them he norm for their actions in making critical policy and legal choices.

\section{The Paris Agreement and energy}

The meta-norm for energy is distinct in that SGDs 7 and 13 have been concretised and normatively reinforced through the Paris Agreement. In a framework convention-cum-protocol approach, the UNFCCC lays down basic principles, operationalised by the Kyoto Protocol until 2020, and the Paris Agreement from 2020 onwards. The Paris Agreement now enshrines the binding objective to limit the global temperature rise to well below 2 degrees Celsius above pre-industrial levels, and to pursue efforts to limit the increase to 1.5 degrees Celsius, while delivering universal access to energy. The Paris Agreement also defines a binding procedure for all states parties, combining the bottom-up Nationally Determined Contributions (NDCs) with the top-down Global Stocktake. The rule-book adopted at COP24 in $2018^{8}$ clarifies the procedure, which is economy-wide but has energy as the indispensable core. International climate action hence becomes energy action and vice-versa.

Human rights provide additional normativity for the meta-norm. This becomes clearer on the backdrop that traditionally human rights had little to say on energy. The International Covenant on Social, Economic and Cultural Rights (ICSECR) ${ }^{9}$ enshrines rights to food and housing among others, which presuppose if not directly guarantee a right to energy in the sense of a right of consumers to access secure, affordable and clean energy. Nevertheless, there has been little guidance on a human right to energy from the CSECR. ${ }^{10}$ But human rights are now demanding of

\footnotetext{
${ }^{6}$ SDG 7: Ensure access to affordable, reliable, sustainable and modern energy for all, https://sustainabledevelopment.un.org/sdg7.

${ }^{7}$ SDG 13: Take urgent action to combat climate change and its impacts, https://sustainabledevelopment.un.org/sdg13.

${ }^{8}$ The Katowice Rulebook is available at: https://cop24.gov.pl/news/news-details/news/the-katowice-rulebook-mainprinciples-of-the-document/.

${ }^{9}$ The International Covenant on Economic, Social and Cultural Rights is a multilateral treaty adopted by the United Nations General Assembly on 16 December 1966 through GA. Resolution 2200A (XXI), and came in force from 3 January 1976.

${ }^{10}$ The Committee on Economic, Social and Cultural Rights (CESCR) is the body of 18 independent experts that monitors implementation of the International Covenant on Economic, Social and Cultural Rights by its States parties. The Committee carries out the monitoring functions assigned in Part IV of the Covenant to the UN Economic and Social Council (ECOSOC)
} 
states positive measures from a functional perspective. The 2016 report of the UN Special Rapporteur of the Human Rights Council on Human Rights and the Environment has identified this human rights normativity for energy policies, ${ }^{11}$ which mandates decarbonisation of energy, or in SDG7 terms, providing sustainable energy. ${ }^{12}$ The positive basis is a human right to a healthy environment where regional instruments provide it. ${ }^{13}$ Human rights also underpin specific energy policies of states, such as policies on flaring in the Niger Delta ${ }^{14}$ or carbon pricing in the port of Rotterdam. ${ }^{15}$ The 2019 report of the Special Rapporteur for Food reinforces, from that perspective, this demand for sustainable energy.

This meta-norm of climate action while delivering universal access to energy then sets the impetus for energy policy and law-making of all states parties, throughout the energy value cycle from generation, through transportation/transmission, to consumption. This impetus is para-prohibitive of certain fossil energy sources and promotional of cleaner alternatives; it favours interconnected global energy markets to balance supply and demand in these alternatives; and it seeks efficiencies. This impetus translates into a regulatory approach to energy (III). It also directs states to reassess the entire gamut of their international cooperation and to align generic commitments with the metanorm (IV).

\section{The international regulatory approach to energy}

This meta-norm generates a single approach to the development of new international law. This approach is for the international regulation of energy throughout its value-chain. Regulation is used here in the sense of the definition that Professor Adler has provided. ${ }^{16}$ Regulation in this

\footnotetext{
${ }^{11}$ Report of the Special Rapporteur on the issue of human rights obligations relating to the enjoyment of a safe, clean, healthy and sustainable environment, UN Doc A/HRC/31/52; Special Rapporteur of the Human Rights Council on Human Rights and the Environment can be found via: https://www.ohchr.org/en/Issues/environment/SRenvironment/Pages/SRenvironmentIndex.aspx.

12 Para 54: "In particular, the Special Rapporteur agrees with the suggestion of UNEP that wherever possible States should assess the climate effects of major activities within their jurisdiction, 'such as programmatic decisions about fossil fuel development, large fossil fuel-fired power plants, and fuel economy standards"'.

${ }^{13}$ Organization of African Unity (OAU), African Charter on Human and Peoples' Rights ("Banjul Charter"), 27 June 1981, CAB/LEG/67/3 rev. 5, 21 I.L.M. 58 (1982).

${ }^{14}$ The Federal Government of Nigeria have taken the initiative to prohibit gas flaring and ensure the utilization of gas flared within the country by oil and gas companies. The Prevention of Waste and Pollution Regulations 2018 seeks to provide legal support to the National Gas Flare Commercialization Program ("NGFCP") (a policy to eliminate gas flaring through technically and commercially sustainable gas utilization projects developed by competent third-party investors invited to participate in a competitive and transparent bid process), and reduce the effect of gas flaring on the environment (a major contributor to global warming). See more at: http://www.mondaq.com/Nigeria/x/756460/Oil+Gas+Electricity/Gas+Flaring+Charges+In+Nigeria.

${ }^{15}$ In the Netherlands, the Port of Rotterdam has made EUR 5 million available via its Incentive Scheme ClimateFriendly Shipping to fund maritime projects using low- and zero-carbon fuel. Shipping companies, fuel and engine manufacturers and suppliers and shipping service providers operating out of the Port of Rotterdam will be able to submit for funding if their project relies on green fuel and carbon reduction options. See more at: https://bioenergyinternational.com/storage-logistics/26426.

${ }^{16}$ M. Adler, 'Regulatory Theory', in: D. Patterson (ed), A Companion to Philosophy of Law and Legal Theory (2nd ed, Blackwell, 2010) 590; The UK Task Force Better Regulation, Principles of Better Regulation (2011), 1; see also
} 
definition aims to achieve public policy goals through legal directives. The international regulation of energy then seeks to achieve the state of affairs indicated by the SDGs/Paris objective through for the entire value-chain of energy. ${ }^{17}$ The design of a dedicated regulatory set-up innovates over traditional international law and pushes its classic doctrinal boundaries, in three characteristic respects. There is an institutionalised architecture to oversee the regulatory change (1); primary regulation of the conduct of private actors and consumers (2), and there is concern for a socially just regulation that advances the welfare of all (3).

\section{An institutional architecture to oversee regulatory change}

The regulation of energy is based on international rule-making. Treaty is too static for this purpose. This requires institutionalised procedures of international rule-making that iterative, it is to be reviewed in regular intervals and progressively strengthened. The starting point is the accountability of states and the corresponding oversight of international organisations.

Accountability is a matter of who is accountable to whom for what. In energy, all states become accountable towards the international community of states as a whole, and through it, humanity. Accountability of all states against SDG 7 and 13 is proceduralised through the High-Level Forum on Sustainable Development (HLPF) under the auspices of the UN Economic and Social Council (ECOSOC) and the General Assembly (GA), which has a central role in the follow-up and review of the 2030 Agenda. ${ }^{18}$ The HLPF conducts so-called voluntary national reviews, which are "voluntary, state-led, undertaken by both developed and developing countries, and shall provide a platform for partnerships, including through the participation of major groups and other relevant stakeholders". ${ }^{19}$ The Voluntary National Reviews aim to facilitate the sharing of experiences by governments, including successes, challenges and lessons learned in implementing the 2030 Agenda. They also seek to strengthen policies and mobilize support and partnerships for the Sustainable Development Goals. The review of policies is thematic and cuts across several SDGs, but reviews some in depth. Such an in-depth review has taken place for SDG7 on affordable and clean energy within the 2018 thematic review for transformation towards sustainable and resilient societies. The 2019 theme of inclusiveness and equality will review, in-depth, SDG 13 on climate action. ${ }^{20}$ In 2019, the High-level Political Forum will be convened twice: first under the auspices of the ECOSOC; and then of the General Assembly, meeting at head of state-level - the first SDG Summit since $2015 .^{21}$

J. H. H. Weiler, 'The Geology of International Law - Governance, Democracy and Legitimacy', (2004) 64 ZaöRV 550.

${ }^{17}$ The international regulation of tobacco consumption and other lifestyle choices is structurally distinct in that is it remains limited to reducing certain (limited) risks from tobacco and alcohol consumption, despite some paraprohibitive traits. See A. Alemanno \& A. Garde (eds), Regulating Lifestyle Risks (CUP, 2015); further D. Byrd \& C. Cothern, Introduction to Risk Analyis (2000).

${ }^{18}$ GA resolution 70/299 provides guidance on the follow-up and review of the 2030 Agenda and the SDGs.

${ }^{19} 2030$ Agenda, para 84.

${ }^{20}$ Further https://sdg.iisd.org/news/discussion-note-identifies-climate-sdg-synergies-ahead-of-sdg-13-review/.

${ }^{21} 47$ states are expected to present their Voluntary National Reviews at the 2019 Forum, 40 of them for the first time. 
This accountability is the basis of international institutionalised oversight. A oversight function of international organisations over mandated legal change has been recognised by the International Court of Justice (ICJ) in its 2019 opinion on the legal consequences of the separation of the Chagos from Mauritius in 1965. ${ }^{22}$ Upon granting independence to its former colony Mauritius, the UK had separated off a part, the Chagos Island, and re-organised it as the British Indian Ocean Territory. The ICJ opined that this was in violation of the then applicable international law of selfdetermination. The UN Charter enshrines a principle of self-determination for people under colonial domination in Art. 1(2) and in Chapter XI on trusteeship. ${ }^{23}$ Importantly, in this opinion, the ICJ recognises the role of the UN and particularly the General Assembly in overseeing the implementation of the principle by the concerned (colonial) states, and to exercise this oversight through appropriate resolutions that concretise the Charter. Hence, only GA resolutions ${ }^{24}$ operationally spelled out that the integrity of the former colony had to be respected upon gaining independence. On this account, the opinion points out that that this has become a rule of customary international law. A general point can then be made: An international rule arises from two elements: formalisation by an international organisation and authorisation. These can occur at different points in time. ${ }^{25}$

This account of institutional oversight elucidates the regulation of energy mandated by the metanorm. Different from other areas of international law, such as health, there is not a single organisation with centralised oversight responsibility for the field. Instead, oversight is decentralised. Organisations such as the Organization of the Petroleum Exporting Countries $(\mathrm{OPEC})^{26}$ and the International Energy Agency (IEA) ${ }^{27}$ have historically organised self-selected groups of states by their antagonistic interests as producers and consumers of energy and particularly for fossil fuels, although the International Energy Forum (IEF) ${ }^{28}$ is to bring both groups together. On the other hand, the International Renewable Energy Agency (IRENA) demonstrates a universal membership-approach at least to renewable energy sources. ${ }^{29}$ The Energy Charter Conference brings energy consumers and producers together across the full energy valuecycle, under the principles of facilitated trade, cooperation and investment protection in energy.

\footnotetext{
${ }^{22}$ International Court of Justice, Legal Consequences of the Separation of the Chagos Archipelago from Mauritius in 1965, Opinion of 25 February 2019.

23 The full text of the UN Charter is available at: https://www.un.org/en/sections/un-charter/un-charter-full-text/.

${ }^{24}$ GA resolutions 1514 (XV) of 14 December 1960, 2066 (XX) of 16 December 1965, 2232 (XXI) of 20 December 1966 and 2357 (XXII) of 19 December 1967.

${ }^{25}$ A fuller account can be found in Volker Roeben; Institutions of International Law', (2019) Max Planck Yearbook of UN Law (in print).

${ }^{26}$ OPEC's objective is to co-ordinate and unify petroleum policies among members, in order to secure fair and stable prices for petroleum producers; an efficient, economic and regular supply of petroleum to consuming nations; and a fair return on capital to those investing in the industry. More information is available via:

https://www.opec.org/opec_web/en/.

27 The IEA is an autonomous organisation which works to ensure reliable, affordable and clean energy for its 30 member countries and beyond. More information is available via: https://www.iea.org/.

28 The International Energy Forum (IEF) aims to foster greater mutual understanding and awareness of common energy interests among its members. More information is available via: https://www.ief.org/.

${ }^{29}$ The Clean Energy Ministerial is an informal forum of intergovernmental cooperation of certain OECD members on clean energies. It is serviced by the IEA.
} 
Multilateral and bilateral development finance institutions enable energy transitions and low carbon energy access. ${ }^{30}$

The Energy Charter Conference can serve as primary reference for dynamic institutionalised oversight over transboundary energy. It operates under the authority of the ECT, which in the 1990s constructed the first international organisational and legal architecture specifically for energy. The ECT aimed at energy market creation. Since its adoption in the 1990s, the ECT provisions have hardly been updated and primarily for the trade dimension. The SDGs and the Paris Agreement now drive a change agenda. There are three, simultaneous phases of a modernisation process of the treaty, which involves infra-treaty and treaty-level rule-making and implementation of the meta-norm.

The 2015 International Energy Charter forms the first phase I of the modernisation process. This non-legally binding instrument was adopted by over 90 signatory states both developing and developed. ${ }^{31}$ It represents the current consensus of signatories on international action on energy. It transforms the Energy Charter process from a European initiative to an international one and rejuvenates the text of that earlier political declaration. It now reflects some of the most topical energy challenges of the 21 st century, in particular the "trilemma" between energy security, environmental protection, and equity. The International Energy Charter strengthens the synergies among energy-related multilateral fora on the need to promote access to modern energy services, energy poverty reduction, clean technology and capacity building. In also reinforces the normativity of the ECT. As a result, several non-Eurasian states have since become parties of the ECT, including Jordan in December 2018 and Yemen in January 2019. ${ }^{32}$ In February 2019, the African Kingdom of Eswatini (formerly Swaziland) announced it was in the final stages of the accession process to the ECT. ${ }^{33}$ The second phase of modernisation involves streamlining the principles of the International Energy Charter without changing the Treaty, developing a range of infra-treaty instruments. ${ }^{34}$ The third phase of the modernisation will aim to revise the provisions of the treaty so that they reflect modern investment standards and embrace stronger provisions on

\footnotetext{
${ }^{30}$ The World Bank, International Finance Corporation and the African Development Bank support a range of renewable energy technology options to help state to supply energy to their populations in a manner consistent with $2{ }^{\circ} \mathrm{C}$ pathways.

${ }^{31}$ States that have adopted the International Energy Charter as of May 2019 are from Asia and the far East (including China), the Gulf, South America and Africa. Further information on the International Energy Charter is available at: https://energycharter.org/process/international-energy-charter-2015/overview/.

${ }^{32}$ Further information on Jordan and the ECT is available at: https://energycharter.org/media/news/article/jordan-isthe-51st-contracting-party-to-the-

ect/?tx_news_pi 1\%5Bcontroller\%5D=News\&tx_news_pi1\%5Baction\%5D=detail\&cHash=333d881595d7cea051a5 $62 \mathrm{c} 0 \mathrm{e} 18 \mathrm{c} 7650$.

${ }^{33}$ Further information on the Kingdom of Eswatini and the ECT is available at: https://energycharter.org/media/news/article/ambassador-of-the-kingdom-of-eswatini-visits-the-energy-chartersecretariat/?tx_news_pi 1\%5Bcontroller\%5D=News\&tx_news_pi1\%5Baction\%5D=detail\&cHash=0e3c889b647037 45dd52aecc828dd8ee.

${ }^{34}$ Infra.
} 
sustainable development, including on climate change and the clean energy transition in line with the Paris Agreement. ${ }^{35}$

To this should be added the institutional set-up of international climate law that rests on meetings of parties. Oversight over energy also is the remit of the institutional set-up under the UNFCCC, Kyoto Protocol and Paris Agreement. These treaties establish the Conference of the Parties to the UNFCCC (COP), the meeting of parties to the Kyoto Protocol (CMP), and the meeting of parties to the Paris Agreement (CMA). The thus organised collectivity of parties oversees the bottom-up determination of energy policy by each party. The COP/CMP/CMA concretises through decisions the general, non-operational provisions of the treaties. The legal status of these decisions typically remains undefined under the constitutive treaties, but they have received increased recognition for the interpretation and application of these treaties. ${ }^{36}$ There is also state-internal enforceability before national courts. National courts are strategically using human rights doctrine to incorporate the standards of the Paris Agreement to hold governments to account for their energy policies. ${ }^{37}$ The positive basis is the general human rights to life and to a private and family life as guaranteed in the European Convention on Human Rights. ${ }^{38}$ In so doing, they have to overcome contrary arguments based on the separation of powers, which, at least in the European context, are limited by the human right to an effective remedy and hence effective judicial review. Such rule-making on energy by meetings of parties also takes place under the Biodiversity Convention for sustainability criteria of biofuels types, or the phase-out of certain fuels in global maritime and air transport, ${ }^{39}$ or again in the development of technical standards for transboundary energy markets.

Transparency of national policies is a crucial element of this accountability. Transparency measures in the energy sector focus increasingly on dissemination of best practices in the renewable energy sector, energy transitions and climate mitigation measures including carbon reporting. Mandatory and voluntary carbon reporting policies are becoming widespread. States that have put mandatory reporting of GHG reporting into legislation, including the UK, EU Member States, the US, Australia, Japan and South Africa. These reports are published in relevant GHG inventories that exists in many parts of the world. ${ }^{40}$ Parties to the Paris Agreement have been negotiating the modalities, procedures, and guidelines for the enhanced transparency framework established under the Agreement (Article 13) since its inception in 2016. Transparency under the Agreement aims to reveal the actions taken by its parties to mitigate and adapt to climate change

\footnotetext{
${ }^{35}$ Part III.

${ }^{36}$ Whaling in Antarctica; ILC Report on subsequent state practice xxx. For a fuller account see Petra Minnerop, [...] (in this volume).

37 The Hague Court of Appeal, Civil-law Division Case number : 200.178.245/01

Case/cause list number : C/09/456689/ HA ZA 13-1396, The State of the Netherlands v Urgenda,

Ruling of 9 October 2018, available https://www.urgenda.nl/wpcontent/uploads/ECLI_NL_GHDHA_2018_2610.pdf (under appeal to the Supreme Court).

${ }^{38}$ Council of Europe, European Convention for the Protection of Human Rights and Fundamental Freedoms, as amended, 4 November 1950, ETS 5.

39 The 1992 Convention on Biological Diversity is dedicated to promoting sustainable development.

40 This list of available GHG inventories can be found at: https://ghgprotocol.org/life-cycle-databases (last accessed on 29.08.2018).
} 
and track the process progress toward implementing and achieving individual nationally determined contributions (NDCs) and to improve the support provided and received by the parties.

The institutionalised regulation of energy hence employs a procedure of international rule-making, infra treaty, that had become entrenched in state practice, ${ }^{41}$ but which is re-affirmed by the intensive use being made of it in this context. This has repercussions for the general doctrine of treaty in international law. Energy regulation contributes to a paradigm slip in the concept of treaty foundational to public international law. ${ }^{42}$ Paradigm shifts are different from full-scale shifts. But the accumulation indicates a slipping of the static consent-based concept of treaty to one that reflects a dynamic understanding of consent.

\section{The regulation of private conduct}

A second defining feature of the international regulatory approach to energy is that is addresses the conduct of non-state actors, corporations and consumers, that is normally only of tangential concern to international law. This has first to do with the fact that this is a field where large, centralised corporations remain dominant, even though energy generation is decentralising as a consequence of the rise of renewables technologies. The role of major energy corporations engaged in upstream extraction, ${ }^{43}$ and of utilities in their capacity as carbon majors remains critical and entails a special responsibility over that of small companies or even individuals.

International regulation of energy seeks not necessarily to prescribe the conduct of these actors, but instead to send signals about priorities and the direction of travel in regulatory change. The UN Global Compact signals to corporations active in the energy sector that they are responsible for upholding international standards. ${ }^{44}$ Principles 1, 2, and 7 of the UN Global Compact demand that businesses support and respect, within their spheres of influence, the protection of human rights and that they adopt a precautionary approach in addressing environmental challenges. International organisations have implemented standards and requirements for human rights and environmental protection responsibilities, including the World Bank Group and the International Finance Corporation (IFC). These include the World Bank's Environmental and Social Standards, ${ }^{45}$ and the IFC's Performance Standards on Environmental and Social Sustainability

\footnotetext{
${ }^{41}$ Further Alan Boyle and Christine Chinkin, The Making of International Law (OUP, 2007).

42 Robin Bradley Kar and Margaret Jane Radin, 'Pseudo-Contract and Shared Meaning Analysis', (2019) 132 Harv

L Rev 1135.

${ }^{43}$ This category comprises both commercial companies and Stata-owned enterprises (SOEs). SOEs are not state organs, although under certain circumstances their conduct may be attributable to a state, see Yukos arbitration, PCA Case 2005-04/AA227, Yukos Universal Limited (Isle of Man) v. The Russian Federation The PCA acted as registry in this arbitration, which was conducted under the UNCITRAL Arbitration Rules (1976) pursuant to the Energy Charter Treaty (1994), in conjunction with PCA Case No. AA 226 (Hulley Enterprises Limited (Cyprus) v. The Russian Federation) and PCA Case No. AA 228 (Veteran Petroleum Limited (Cyprus) v. The Russian Federation), Final Award 18 July 2014.

${ }^{44}$ Information on the UN Global Compact us available at: https://www.unglobalcompact.org/, and the 10 Principles of the UN Global Compact are available at: https://www.unglobalcompact.org/what-is-gc/mission/principles.

${ }^{45}$ Further information of the World Bank's Environmental and Social Standards is available at: https:/www.worldbank.org/en/projects-operations/environmental-and-social-framework/brief/environmental-andsocial-standards.
} 
(latest version in 2012). ${ }^{46}$ The normativity is also effective in the context of the ongoing modernization of the ECT. In 2019, the European Commission has proposed that the treaty contribute to the promotion of human rights and international labour standards, including through provisions on transparency and corporate social responsibility/responsible business conduct. ${ }^{47}$

An early example of the influence of such human rights and environmental principles on corporate action in the energy sector relates to the Baku-Tbilisi-Ceyhan ("BTC") oil and gas pipeline project which carries up to a million barrels of oil a day over a thousand miles across the Caspian region. in 1999, the states of Turkey, Azerbaijan and Georgia entered into an intergovernmental agreement to develop the BTC Pipeline, and between 1999 and 2002, host government agreements were entered between the states and a consortium of corporate companies, with BP as project operator. BP sought to establish a new benchmark for a major infrastructure project. To this effect, BP incorporated into core project documents a commitment to respect applicable standards articulated in the UN Universal Declaration of Human Rights (UDHR), the Tripartite Declaration of Principles established by the International Labour Organization (ILO), and the Guidelines for Multinational Enterprises promulgated by the Organization for Economic Cooperation and Development (OECD). BP caused the BTC Pipeline host governments of Turkey, Azerbaijan and Georgia to enter into a "Joint Statement" ${ }^{48}$ guaranteeing adherence to internationally recognized human rights, labour rights, and environmental standards, including a commitment to the standards espoused in the Voluntary Principles on Security and Human Rights (Voluntary Principles). The BTC Company also signed a legally binding Human Rights Undertaking ${ }^{49}$, designed to protect the rights of the three host governments to promote and regulate human rights and environmental issues.

The signalling effect of the Paris Agreement and its objectives is reflected in the current oil majors' strategies. ${ }^{50} \mathrm{~A}$ recent voluntary undertaking is Royal Dutch Shell's decision to invest $\$ 300$ million over three years in reforestation projects, including in the Netherlands and Spain. This initiative aims to offset the carbon emissions produced when customers consume the fossil fuels that Shell produces and is creating a program to allow drivers to support the company's purchase of carbon credits from ecoprojects. This company plans to double the investment in new energy forms to $\$$

\footnotetext{
${ }^{46}$ Further information of the IFC's Performance Standards is available at: https://www.ifc.org/wps/wcm/connect/Topics_Ext_Content/IFC_External_Corporate_Site/Sustainability-AtIFC/Policies-Standards/Performance-Standards. I have added the World Bank and IFC Standard because the BTC Joint Statement and Human Rights Undertaking mention World Bank Group Standards. They do not mention the UN Global Compact, so we cannot attribute the changes in the BTC agreements to the UN Global Compact. We can generally attribute to human rights and environmental principles.

${ }^{47}$ Commission proposal for a negotiating mandate and annex available at: http://trade.ec.europa.eu/doclib/press/index.cfm?id=2017.

${ }^{48}$ Baku-Tbilisi-Ceyhan Joint Statement, 11 May 2003, available at:

https://subsites.bp.com/caspian/Joint\%20Statement.pdf.

49 Baku-Tbilisi-Ceyhan Human Rights Undertaking, 22 December 2003 available at: https://subsites.bp.com/caspian/Human\%20Rights\%20Undertaking.pdf.

${ }^{50}$ Shell published its energy transition report in April 2018, available at https://www.shell.com/energy-andinnovation/the-energy-future/shell-energy-transition-report.html.
} 
4 billion per year. ${ }^{51}$ The effect extends to the level of shareholders using corporate governance instruments to bring about changes in company strategy. At the same time international finance institutions and pension funds are divesting away from extreme fossil fuels. As an example, the World Bank will end its financial support for oil and gas extraction within the next two years. The Bank already ceased lending for coal-fired power stations in 2010.

Public international bodies reinforce this signal through incentives and voluntary instruments. Signal-based public-private cooperation to scale new clean technologies is being used under the informal Clean Energy Ministerial, for instance in its initiative to promote hydrogen throughout its value-chain. ${ }^{52}$ The Energy Charter Secretariat has established an Industry Advisory Panel (IAP) in 2004 to strengthen the dialogue with the private energy sector in line with international regulatory objectives. ${ }^{53}$ The IAP provides policy advice from energy companies, international business associations and financial institutions on energy investment and the functioning of energy markets. In 2001, the Energy Charter Secretariat set up a voluntary Legal Advisory Task Force (LATF) of experts inter alia from private companies and SOEs to assist in the drafting Model Agreements on Cross-Border Pipelines and Electricity Lines on the transport of energy materials and products across borders. ${ }^{54}$ These Model Agreements standardise the host-government agreements signed typically between states involved in the project and between the project company and host states. The first Model Agreements were published in 2004 and were updated last in $2008 .{ }^{55}$ From 2018, the modernisation phase II has focused on adapting the Model Agreements. ${ }^{56}$ This modernisation has also involved signal-based regulation of corporate conduct in case of emergencies. In 2004, in response to reoccurring energy transit interruptions and its major implications on energy access, the Energy Secretariat developed an Early-Warning Mechanism. This mechanism is for voluntary acceptance by parties, providing a tool for transparency, exchange of information, consultation, and verification (monitoring) ${ }^{57}$ For instance,

\footnotetext{
${ }^{51}$ Media release available at: https://www.shell.com/media/news-and-media-releases/2019/shell-invests-in-natureto-tackle-co2-emissions.html.

52 The Hydrogen Initiative will leverage and benefit from the knowledge, expertise and early investments made by both the private and public sectors. Leading industry stakeholders and collaborative forums such as the Hydrogen Council will contribute to work undertaken through the initiative. 'Countries launch a new international effort on hydrogen to help achieve global clean energy ambitions’, 29 May 2019, available at https://www.cleanenergyministerial.org/news/.

${ }^{53}$ Further information on the Energy Charter Secretariat's IAP is available at: https://energycharter.org/who-weare/industry-advisory-panel/.

${ }^{54}$ Dr Gokce Mete had served in the LATF of the Energy Charter Secretariat prior to joining the Secretariat full time in February 2019. The knowledge shared here is based on her involvement in the LATF.

55 Energy Charter Model Agreements, available at: https://energycharter.org/what-we-do/trade-and-transit/modelagreements/.

${ }^{56}$ Further information on the update of the Energy Charter Model Agreements on Cross Border Pipelines available at: https://energycharter.org/media/news/article/technical-subgroup-on-transit-holds-its-secondmeeting/?tx_news_pi 1\%5Bcontroller\%5D=News\&tx_news_pi 1\%5Baction\%5D=detail\&cHash=0925febe267437c2 badb9f6274600820.

${ }^{57}$ Energy Charter, Early Warning Mechanism, available at: https://energycharter.org/media/news/article/the-energycharter-early-warning-mechanism-2014-russia-ukraine-eu-transitissues/?tx_news_pi $1 \% 5 \mathrm{Bcontroller} \% 5 \mathrm{D}=$ News\&tx_news_pi1\%5Baction $\% 5 \mathrm{D}=$ detail\&cHash=3aa4c1424688c6325b $0 \mathrm{~d} 34 \mathrm{a} 87 \mathrm{~d} 5 \mathrm{ddaf} 9$.
} 
in July 2016, Ukraine's SOE, Naftogaz, wrote to the European Commission informing about gas pressure irregularities in the main gas transmission system and proposing the use of existing ECT procedures such as the Early Warning Mechanism..$^{58}$

The international law of energy, driven by a meta-norm, goes beyond regulating private operations of incumbents, and it ultimately aims at social welfare maximisation. While this is the aim of regulation in all sectors of the economy, in the sphere of energy it sets public policy objectives that are underpinned by the scientific expertise that the Intergovernmental Panel on Climate Change $(\text { IPCC })^{59}$ provides. At the same time, the means of achieving these objectives are subject to the parameter of cost-effectiveness. Cost-effectiveness determines preference for market-based instruments that incentivise private investment in cleaner energy. For instance, the polluter-pays principle that internalises environmental costs was first established in international environmental law and applied to quintessentially to environmental problems, such as levels of pollutants in air, land or water. The principles of international environmental law reflect an understanding of 'principle' as a norm of unlimited application. ${ }^{60}$ The regulatory approach now extends their application to the specifics of energy, such as the carbon emissions that are the by-products of energy production, transport and consumption. ${ }^{61}$

That rationale can be achieved through indirectly effective international rules, obligating states to license or otherwise control private conduct. The classic example is deep seabed mining under the 1982 UN Convention on the Law of the $\mathrm{Sea}^{62}$. The convention directly prescribes states' licensing of operators and indirectly the conduct of the licensed operators in mineral resource exploitation. ${ }^{63}$ For energy, such indirect, legal regulation is performed by the EU's Emissions Trading System (ETS) for utilities and similar emissions trading schemes. ${ }^{64}$ Under these schemes, states are to license the energy operators and allocate maximum carbon emissions allowances which can be traded, in order to indirectly steer their conduct. This indirect regulation is being extended

\footnotetext{
${ }^{58}$ Further information on the Naftogaz proposal for the Early Warning Mechanism available at: https://energycharter.org/media/news/article/naftogaz-proposed-to-use-model-energy-charter-early-warningmechanismnaftogaz-

predlo/?tx_news_pi1\%5Bcontroller\%5D=News\&tx_news_pi1\%5Baction $\% 5 \mathrm{D}=$ detail\&cHash $=670 \mathrm{~d} 1 \mathrm{~b} 49 \mathrm{~b} 65 \mathrm{bfea} 5 \mathrm{~d}$ aaf873c69076074.

${ }^{59}$ This list of available GHG inventories can be found at: https://ghgprotocol.org/life-cycle-databases (last accessed on 29.08.2018). ipcc.ch/" https://www.ipcc.ch/.

${ }^{60}$ Further Neil MacCormick, Institutions of Law (Oxford University Press, 2007).

${ }^{61}$ That being said, regulation also aims at creating markets and incentives to invest - and in some respect it relates to profit maximisation / or at least reasonable return of the investment.

${ }^{62}$ United Nations Convention on the Law of the Sea, signed 10 December 1982, entered into force 16 November 1994, UNTS vol 1833 (p.3), 1834 (p.3), 1835 (p.3).

${ }^{63}$ International Tribunal for The Law of The Sea Reports of Judgments, Advisory Opinions and Orders, Responsibilities and obligations of States sponsoring persons and entities with respect to activities in the Area (Request for Advisory Opinion Submitted to The Seabed Disputes Chamber) List of cases: No. 17, Advisory Opinion of 1 February 2011.

${ }^{64}$ The EU emissions trading system (EU ETS) is a cornerstone of the EU's policy to combat climate change and its key tool for reducing greenhouse gas emissions cost-effectively. It is the world's first major carbon market and remains the biggest one. A detailed overview of EU ETS is available via: https://ec.europa.eu/clima/policies/ets_en.
} 
throughout the energy value-chain to consumption. For instance, the International Civil Aviation Organisation (ICAO) now operates a system of voluntary State Action Plans on climate action by member states. $^{65}$ Further, under the ICAO Assembly Resolution A39-3, international air companies will be accountable for their consumption and will have to offset their carbon emissions. ${ }^{66}$

The meta-norm of the SDGs and Paris objectives also promotes reduction of energy consumption, that is energy efficiency. ${ }^{67}$ The Energy Charter Protocol for Energy Efficiency and Related Environmental Aspects ${ }^{68}$ responds to this parameter in setting international legal principles designed to promote energy efficiency. The Protocol obligates states to cooperates to implement state-specific policies and to create market conditions to scale up investments in energy efficiency.

3. Social justice, solidarity and fairness

Regulation for sustainable and clean energy is disruptive of the status quo. Energy regulation has necessarily distributive and re-distributive consequences between and within states. It entails parameters of social justice to steer this regulatory change. ${ }^{69}$ Social justice, in this context, has two aspects, solidarity and fairness. International regulation of energy hence pushes another doctrine of international law, that states are primarily responsible to serve the needs of their people.

SDG 7 demands that all have access to sustainable and affordable clean energy, and in particular to electricity. Ensuring such access becomes a prerequisite of social justice that applies worldwide. It also underpins a claim of developing fossil resource-endowed states to solidarity in making the required transition in response to the claim. That claim is being honoured through mechanisms such as technology transfer, international research, development support, and foreign direct investment, as well as capacity-building programmes, in order to speed up the spread of cleanenergy technologies in developing countries. For instance, the ECT promotes and supports technological solutions and improving access to clean and affordable energy, promoting regional market integration to secure energy transition, and promoting clean and smart energy technologies. ${ }^{70}$ The Paris Agreement envisages technology development and transfer for both

\footnotetext{
65114 ICAO member states had submitted their State Action Plans by May 2019. Further information on ICAO climate action State Action Plans available at: https://www.icao.int/environmentalprotection/Pages/ClimateChange_ActionPlan.aspx

${ }^{66}$ Carbon Offsetting and Reduction Scheme for International Aviation (CORSIA), ICAO, Assembly Resolution A39-3: 'Consolidated statement of continuing ICAO policies and practices related to environmental protection Global Market-based Measure (MBM) scheme'. Available at: https:/www.icao.int/environmentalprotection/documents/resolution_a39_3.pdf

${ }^{67}$ Energy efficiency is a cost measure but also a means to change consumer behaviour. EE is about behaviour of individuals and companies, and $\mathrm{Co} 2$ reduction and trade initiatives, while the polluter pays principle focuses on regulating behaviour of companies.

${ }^{68}$ More information on the Protocol on Energy Efficiency and Related Environmental Aspects (PEEREA) is available at: https://energycharter.org/process/energy-charter-treaty-1994/energy-efficiency-protocol/.

${ }^{69}$ M. Adler, 'The normative foundation of risk regulation', (2003) 87 Minnesota L Rev 1293.

${ }^{70}$ Article 8 of the ECT.
} 
improving resilience to climate change and reducing GHG emissions. ${ }^{71}$ It establishes a Technology Mechanism to this effect. ${ }^{72}$

A second aspect of social justice relates to fairness. This concerns the disruptive effect of an energy transition on the skilled workforces in many states employed in the extractive industry. The international climate action under the UNFCCC recognises this, as in 2018 the 24th meeting of the conference of the parties to the UNFCCC resolved in the Silesia Declaration on 'Solidarity and the Just Transition' ${ }^{73}$ The declaration aims to develop such measures focused on new skills as well as new infrastructure for the regions concerned.

\section{From the plural, international law on energy to the international law of energy through re-alignment with the meta-norm}

Energy is a horizontal matter, cutting across all established branches of international law. The traditional international law on energy is hence marked by the plurality of concerns and objectives that these branches serve. This plurality can be assorted on to two tiers. One is energy-specific international law, and it mostly comprises the multilateral ECT and intergovernmental agreements on supply and infrastructure. Much more voluminous is the second tier comprising international law that is not energy specific. This extant international law is serving plural objectives concerns that are non-specific to energy. Its rules may apply to energy falling within its scope ratione materiae as much as they do to other objects. Despite the cognitive dominance of the principle of permanent sovereignty over natural (energy) resources, the non-energy specific international law covers several trans-boundary aspects of energy. A good illustration is investment law, the branch of international law developed to ensure legal certainty for foreign direct investments. It applies to all investments, including in upstream and downstream energy. It remains generic, even if a large percentage of all investment arbitration actually concerns energy.

As a result of the universal collective action on SDG7 and the Paris objective, the meta-norm for energy now re-defines the relationship with extant international law. There is an impetus for all international law that applies to energy to re-align itself with the demands of the new meta-norm. This realignment underpins the conceptual pivot from an international law on energy to the international law of energy.

This section considers this realignment in depth. Re-alignment is a not a hierarchical-central affair. Rather, it is an autonomous process within each branch of international law. For present purposes, these branches shall be understood as regimes, capable of autonomous processes of realignment

\footnotetext{
${ }^{71}$ This list of available GHG inventories can be found at: http://ghgprotocol.org/life-cycle-databases.

${ }^{72}$ Technology Mechanism consists of two bodies: the Technology Executive Committee and the Climate

Technology Centre and Network. They work together to enhance climate technology activities. More information can be accessed via: https://unfccc.int/ttclear/support/technology-mechanism.html.

${ }^{73}$ Silesia Declaration is available at:

https://cop24.gov.pl/fileadmin/user_upload/Solidarity_and_Just_Transition_Silesia_Declaration_2_.pdf. See also European Council Conclusions on the EU strategic agenda, 20/21 June 2019, para $\overline{4}$.
} 
by making use of the procedures and instruments for its developments that each regime has developed. In each regime, realignment becomes manifest as a shift from a generic status quo to a novel energy-specific position that absorbs the demands of climate action. Such realignment is observable in the international law regimes of trade, investment, infrastructure, and trans-boundary resource management.

\section{A re-alignment of world trade law on energy}

Trans-boundary trade in energy is subject to world trade law in goods and services. This trade law is international law on energy in the above described sense. It follows the rationale of comparative advantage that dominates this sector of international law. ${ }^{74}$ Energy is, in all its forms, to be considered as a good to which the generic principles and rules of world trade law applies. That is true for commodities such as oil and gas and also for electricity. ${ }^{75}$ It is to be acknowledged that the disciplines of world trade law have not worked too well for energy. This has to do with the fact that direct import tariffs have played a small practical role. Also, the control on national local content rules is weak, and non-discriminatory access to upstream energy is not really the remit of world trade law either. Nevertheless, the current negotiations between the USA and China on trade demonstrate the role of tariffs on goods for the demand of energy and hence its price.

However, world trade law is re-aligning itself to the implementation of the meta-norm of a climate action-driven energy transition. This is reflected in the evolving WTO case law on energy that accommodates national support schemes for renewables. ${ }^{76}$ More generally, this realignment uses the instrument of regional or bilateral preferential trade agreements. Absorbing the impetus of climate action, these instruments serve to use trade benefits to drive energy policies.

Preferential trade agreements with third states are now an essential tool of the EU's commercial policy, which under the Lisbon Treaty, also encompasses the exclusive competence for substantive investment protection as well as a shared competence with the member states for investor-statedispute settlement. The generic negotiating objectives of the EU for its preferential trade agreements is to include a dedicated chapter for trade in energy that provides access to the partners' energy markets and resources, as well as reduced tariffs for clean energy technology. ${ }^{77}$ In the latter respect, the EU is following the lead of the Association of Southeast Asian Nations (ASEAN). ${ }^{78}$

\footnotetext{
74 Dennis Patterson \& Ari Arifalo, The New Global Trading Order: The Evolving State and the Future of Trade, (Cambridge University Press, 2008).

75 Volker Roeben, Towards a European Energy Union (Cambridge University Press, 2018) 72. Also see T. Cottier et al, 'Energy in WTO law and policy' (WTO Publication, 2008) (energy as service); M. Desta, 'The GATT/WTO System and International Trade in Petroleum', (2003) 21 Journal of Energy \& Natural Resources Law 385.

${ }^{76}$ See Roeben, op cit, 75.

${ }^{77}$ For instance, Commission, Transatlantic Trade and Investment Partnership, EU TEXTUAL PROPOSAL Energy and Raw Materials, 14 July 2016, available http://trade.ec.europa.eu/doclib/docs/2016/july/tradoc_154801.pdf.

${ }^{78}$ ASEAN is a regional intergovernmental organization comprising ten countries in Southeast Asia, which promotes intergovernmental cooperation and facilitates economic facilitates economic, political, security, military, educational, and sociocultural integration among its members and other countries in Asia. More information is available via: https://asean.org/.
} 
Post-Paris Agreement, a new generation of EU preferential trade agreements integrate the demands of the climate action meta-norm. These agreements couple trade preference and the multilateral environmental agreements (MEAs) in force for the parties. Compliance with those MEA becomes an obligation under the preferential trade agreement, and non-compliance is subject to dispute settlement under that agreement. The EU-Canada Comprehensive Economic and Trade Agreement $(\mathrm{CETA})^{79}$ undertakes this integration through Chapter 24 on trade and environment. Under Art. 24.6, a sub-committee of the CETA Joint Committee, the Committee on Trade and Sustainable Development, shall oversee the implementation of this chapter. Hence, there is an institutional mechanism for infra-treaty dynamic integration into the clause of novel MEA. From 2017, the EU and Canada have been deliberating integrating into the CETA climate action obligations resulting from the Paris Agreement. ${ }^{80}$ The CETA Joint Committee has affirmed "the Parties' commitment to effectively implement the Paris Agreement, as a multilateral agreement within the meaning of Art. 24.4 of CETA". The commitment "recommends that the Parties cooperate, work together and take joint action relevant to address climate change and promote the mutual supportiveness of trade and climate policies, rules and measures thereby contributing to the purpose and goals of the Paris Agreement and the transition to low greenhouse gas emissions." 81 The effectiveness and enforceability of integrating such provisions in the trade agreements remain to be tested. The 2017 opinion of the European Court of Justice (ECJ) on the EU-Singapore Free Trade Agreement $(\text { FTA })^{82}$ provides an important pointer. The ECJ not only emphasised the direct and immediate effect of sustainability on trade. ${ }^{83}$ The Court also opined that aspects of trade agreements could be suspended if there was a breach of the sustainability chapter. Such a breach would qualify as 'material' within the meaning of the Vienna Convention on the Law of Treaties. The 2019 EUJapan Economic Partnership Agreement (EPA) is the first with an explicit reference to the Paris Climate Agreement. ${ }^{84}$ Under the EPA, Japan and the EU, "strive to facilitate" trade in renewable

\footnotetext{
79 The Comprehensive Economic and Trade Agreement is a free-trade agreement between Canada, the European Union and its member states. The treaty, that has been provisionally applied, has eliminated $98 \%$ of the tariffs between Canada and the EU. The negotiations were concluded in August 2014. The agreement was signed on 30 October 2016 and the European Parliament gave its consent to CETA during its Plenary session of 15 February 2017. CETA entered into force provisionally on 21 September 2017, in accordance with article 218(5) TFEU. ${ }^{80}$ Commission Staff Working Document, Individual reports and info sheets on implementation of EU Free Trade Agreements (SWD(2018) 454) 31 October 2018, p. 19.

${ }^{81}$ The recommendation of the CETA joint committee on trade, climate action and the Paris Agreement is available at: http://trade.ec.europa.eu/doclib/docs/2018/september/tradoc_157415.pdf.

${ }^{82}$ Opinion 2/15 of the Court (Full Court) of 16 May 2017.

${ }^{83}$ Opinion 2/15, para 158. "Such effects result, first, from the commitment of the Parties, stemming from Article 13.1 .3 of the envisaged agreement, on the one hand, not to encourage trade by reducing the levels of social and environmental protection in their respective territories below the standards laid down by international commitments and, on the other, not to apply those standards in a protectionist manner...."

${ }^{84}$ Art. 16.4(4) of EPA reads: "... The Parties reaffirm their commitments to effectively implement the UNFCCC and the Paris Agreement, done at Paris on 12 December 2015 by the Conference of the Parties to the UNFCCC at its 21 st session. The Parties shall cooperate to promote the positive contribution of trade to the transition to low greenhouse gas emissions and climate-resilient development. The Parties commit to working together to take actions to address climate change towards achieving the ultimate objective of the UNFCCC and the purpose of the Paris Agreement".
} 
energy and other low-carbon solutions to combat climate change. ${ }^{85}$ It remains to be seen whether membership of the Paris Agreement, that is the ratification or the non-exit from that agreement, is made a condition by the EU for it to conclude a preferential trade agreement. The negotiations with the USA may prove a test case. ${ }^{86}$

Other economic and trading blocs employ preferential trade agreements in a similar fashion. The 2018 reformed Trans-Pacific Partnership, the Comprehensive and Progressive Agreement for Trans-Pacific Partnership (CPATPP), ${ }^{87}$ has about two-thirds of its provisions identical to the TPP draft at the time the USA was in the negotiating process. The energy-relevant Chapter 17 on stateowned enterprises (SOEs) is unchanged, requiring signatories to share information about SOEs with each other, with the intent of engaging with the issue of state intervention in markets. Chapter 22 on the environment is also preserved. TPP provisions that were priorities of the US were suspended or modified from the CPTPP, including the provision for companies to sue governments over strict regulations over oil and gas developments. The 2018 US - Mexico - Canada Agreement (USMCA), which is a renegotiation of the North American Free Trade Agreement (NAFTA), actually enhances energy trade. ${ }^{88}$ The investor-state dispute resolution provision adds protection for oil and gas, infrastructure, and energy generation; there is support for deepening cross-border ties in the energy sector and also a new chapter on anti-corruption and a separate stand-alone chapter on the environment.

\section{Re-alignment of international law on energy investment}

Trans-boundary investment in energy is subject to the international law on investment protection and investor-state-dispute settlement (ISDS). Apart from the ECT, this international law is laid down in a web of bilateral treaties. Upstream energy, whether non-renewable or renewable, is generally considered an investment to which the generic protective rules pre and post-admission of any investment apply. This general rationale of legal stability of this international law hence also covers energy.

However, a realignment of international investment law with the meta-norm of climate action is under way, providing an energy-specific focus. Investment law moves from stability for investors (and compensation in the event of changes) to a rationale of flexibility and proportionality, in which a regulatory measure that meets a legitimate objective and constitutes suitable and necessary

\footnotetext{
${ }^{85}$ Art. 16.5(c) of EPA reads: "[the Parties] shall strive to facilitate trade and investment in goods and services of particular relevance to climate change mitigation, such as those related to sustainable renewable energy and energy efficient goods and services, in a manner consistent with this Agreement".

${ }^{86}$ European Parliament, Draft motion for a resolution on the recommendations for opening of trade negotiations between the EU and the US (2019/2537(RSP)).

87 Comprehensive and Progressive Agreement for Trans-Pacific Partnership, Santiago, 08 March 2018. On 30 December 2018, the agreement entered into force between Australia, Canada, Japan, Mexico, New Zealand, and Singapore, and on 14 January 2019 for Vietnam. Summaries of the CPATPP provisions are available at: https://international.gc.ca/trade-commerce/trade-agreements-accords-commerciaux/agr-acc/cptppptpgp/chapter_summaries-sommaires_chapitres.aspx?lang=eng\#20.

${ }^{88}$ Agreement between the United States of America, the United Mexican States, and Canada, signed 30 November 2018, not yet in force, text available at: https:/ustr.gov/trade-agreements/free-trade-agreements/united-statesmexico-canada-agreement/agreement-between. The agreement has different titles.
} 
means of implementation is lawful and does not entail a duty to compensate investors. Aligned with the meta-norm of climate action, international investment law permits states to have a flexible regulatory policy on energy-related matters. This flexibility permits host states to introduce but also to exit support for clean energy investments.

This alignment is well reflected in the new generation EU preferential trade agreements. ${ }^{89}$ These carve out a regulatory space for the host state of the investment. There is a list of legitimate public policy concerns that includes climate related action. The agreements also provide that a change in the law per se does not violate the legitimate expectations of investors.

This same alignment is manifest in the ECT context, which is the only multilateral investment protection regime that applies specifically to energy. It is today the most litigated investment agreement in the world, with a total of more than 120 notified disputes. As originally conceived, this regime served the apply the general rationale of legal certainty to trans-boundary mainly upstream energy investments. The Treaty promotes foreign investment in the energy sector in its over 50 contracting parties in Part III of the Treaty, and protects investments made against the most important political risks, such as discrimination, expropriation and nationalisation, breach of individual investment contracts, damages due to war and similar events, and unjustified restrictions on the transfer of funds. The dispute settlement provisions of the Treaty, covering both state-tostate arbitration and investor-state dispute settlement, reinforce these investor rights. As there has been a surge of renewable energy investments across its constituency, the majority of the case law in recent years, particularly involving Southern Europe, have evolved around finding the right balance between a state's right to regulate to meet evolving circumstances and the protection of an investor's immutable economic rights. The Southern European host states concerned had phased out subsidies for renewables, and this triggered investment disputes under the ECT. Many of these cases are ongoing but the outcome of some of these cases are presenting a division among arbitral tribunals over this equilibrium between the need for a stable and predictable investment framework and the right of states to regulate. The general reason for inconsistent outcomes is that especially in the case of Spain, the cases relate to different incentives introduced in different times. ${ }^{90}$ In some cases concerning Italy, in addition to the incentives provided by regulation, there were express assurances provided by the states that no amendments would occur and this had a significant role on tribunals' decision. ${ }^{91}$

The uneven outcome of ECT renewable energy arbitral awards calls for a realignment of the investment law regime. Climate action goals push towards the right of states for policy entry and exit on the support that renewable technology required at least initially, but which becomes less important as grid parity is being reached and which support can then de devoted to newer clean

\footnotetext{
${ }^{89}$ See the Singapore and the Japan FTAs discussed above.

${ }^{90}$ Charanne B.V., Construction Investments S.A.R.L. v Spain, SCC Arbitration No.: 062/2012 (“Charanne”); Eiser Infrastructure Limited and Energia Solar Luxembourg S.a.r.1. v Spain, ICSID Case No. ARB/13/36 ("Eiser”)

${ }^{91}$ Jürgen Wirtgen, Stefan Wirtgen, Gisela Wirtgen, JSW Solar (zwei) GmbH \& Co. KG v. The Czech Republic ("Wirtgen”) PCA Case No. 2014-03; Blusun S.A., Jean-Pierre Lecorcier and Michael Stein v. Italy, ICSID Case No. $\mathrm{ARB} / 14 / 3$ ("Blusun"); and Charanne.
} 
technologies. The European Commission has noted in May 2019 that the ECT rules on investment protection are no longer sustainable or adequate for the current challenges. ${ }^{92}$ The Commission recommends that the modernisation of the ECT should aim at a high level of investment protection with provisions affording legal certainty for investors and investments of Parties in each other's market. Treaty texts could be rigid and changing them requires consensus, which is not always easy to reach when a challenging balance is being sought. The Energy Charter Secretariat has hence produced soft-regulation to modernise the Treaty investment regime, short of treaty-change. As part of its modernisation phase II, in 2014, the Secretariat established a Conflict Resolution Centre $^{93}$ which provides assistance with mediation and conciliation, neutral, independent legal advice and assistance in dispute resolution. In 2017, a Guide on Investment Mediation which aims to promote amicable dispute settlement in investor-state disputes was published. The Energy Charter Secretariat also has an Investment Facilitation Toolbox focused on removing barriers to establishment of energy investments. The Handbook on General Provisions Applicable to Investment Agreements in the Energy Sector ${ }^{94}$ collates different policies and clauses available when negotiating an investment agreement. The Energy Investment Risk Assessment (EIRA) ${ }^{95}$ publication assists governments improve investment conditions for foreign investors in the energy sector, increasingly focusing on renewable energy investments.

There is, of course, a limit to what can be achieved with soft law instruments. In November 2017, the Energy Charter Conference launched a discussion on the potential modernization of the treaty text. ${ }^{96}$ In 2018, the topics for modernisation were approved..$^{97}$ Around a third of the provisions to be revised concern investment promotion and protection in the energy sector in line with the SDGs and Paris Agreement. The Contracting Parties to the ECT are renegotiating new policy options for topics, among others, of pre-investment, definition of 'economic activity in the energy sector', definition of investment and of investor, right to regulate, definition of Fair and Equitable Treatment (FET) and Most-Favoured Nation (MFN) clause, definition of indirect expropriation, compensation for losses, as well as the novel concepts of transparency, sustainable development and corporate social responsibility. If a consensus can be reached in due time, this will present a fundamental milestone in re-alignment of international investment regulation. This quasi-universal re-alignment under the ECT is likely to entail a re-alignment of the international investment law

\footnotetext{
92 See the Commission proposal for a negotiating mandate and annex available at: http://trade.ec.europa.eu/doclib/press/index.cfm?id=2017.

${ }^{93}$ In 2014 the Energy Charter Conference mandated the Secretariat to the assist with good offices, mediation and conciliation, as well as to provide neutral, independent legal advice and assistance in dispute resolution and participate in pre-trial proceedings between Contracting Parties before they revert to the mechanisms contained in Art. 27 ECT or Annex D.

${ }^{94}$ Handbook on General Provisions Applicable to Investment Agreements in the Energy Sector is available at: https://energycharter.org/fileadmin/DocumentsMedia/Other_Publications/20171116-newHandbook.pdf.

${ }^{95}$ Energy Investment Risk Assessment (EIRA) publication is available via: https://energycharter.org/what-wedo/investment/energy-investment-risk-assessment-eira/.

${ }^{96}$ Commission proposal for a negotiating mandate and annex, available at: http://trade.ec.europa.eu/doclib/press/index.cfm?id=2017.

97 Full list of approved topics for the Modernisation is available here:

https:/energycharter.org/media/news/article/approved-topics-for-the-modernisation-of-the-energy-charter-treaty/.
} 
of energy beyond that treaty. The start of the negotiations to modernise the Energy Charter Treaty will ultimately be decided by the Energy Charter Conference. It is expected that this will be still in 2019. Indeed, on 15 July 2019 the European Council adopted two negotiation directives for modernisation of ECT which aim to focus on ensuring that climate change and clean energy transition goals are reflected in the modernised ECT. ${ }^{98}$

\section{Re-alignment of international law on energy infrastructure}

All trans-boundary trade and delivery of energy is infrastructure bound. This is the case for fossil sources - pipelines for oil and gas, ports and facilities for Liquified Natural Gas (LNG) - as well as for electricity generated from renewables and transmitted through cables. This infrastructure is subject to a plurality of international law. The Law of the Sea applies to marine infrastructure. A host of Intergovernmental Agreements (IGA) between the participating states govern both marine and terrestrial infrastructure projects, these supplemented by the private, transnational consortia that actually build the project.

The emergence of the meta-norm of climate action has had consequences for this international law. For instance, the meta-norm provides impetus to develop dedicated international law for the LNG infrastructure, given that gas is bridge fuel in the energy transition. In the restarted trade agreement negotiations between the US and the EU, this underpins the EU's readiness to import LNG through an expanded re-liquefaction infrastructure. ${ }^{99}$ Between the EU and the US and between the EU and Japan, dedicated bilateral bodies have been set up to this effect. ${ }^{100}$ The Energy Charter Secretariat has established an LNG task force to work on bolt-on, flexible model clauses, as part of the modernisation phase II process.

In the electricity sector, new challenges and concepts of regulation are emerging as trans-boundary grid networks become more widespread. ${ }^{101}$ Their operation requires regulatory systems to foster transnational network interconnections and unrestrained power transit under international law. The EU single electricity market regulation currently provides the most elaborate framework for

\footnotetext{
98 Press Release, Council adopts negotiation directives for modernisation of Energy Charter Treaty on 15 July 2019 , available at: https:/www.consilium.europa.eu/en/press/press-releases/2019/07/15/council-adopts-negotiationdirectives-for-modernisation-of-energy-charter-treaty/.

99 Joint U.S.-EU Statement following President Juncker's visit to the White House, Washington, 25 July 2018 , available http://europa.eu/rapid/press-release_STATEMENT-18-4687_en.htm ; EU-U.S. Joint Statement: Liquefied Natural Gas (LNG) imports from the U.S.

continue to rise, up by $181 \%, 8$ March 2019 available at: https://ec.europa.eu/energy/en/news/eu-us-joint-statementliquefied-natural-gas-lng-imports-us-continue-rise-181-0.

${ }^{100}$ Memorandum of Cooperation between the European Commission, on behalf of the European Union, and the Ministry of Economy, Trade and Industry of Japan on Promoting and Establishing a Liquid, Flexible and Transparent Global Liquefied Natural Gas Market in the context of enhancing the EU - Japan cooperation on secure and sustainable energy, 11 June 2017 available at:

https:/ec.europa.eu/energy/sites/ener/files/documents/japanmoc2017_energy.pdf.

${ }^{101}$ Rafael M. Plaza, 'Transnational power transmission and international law', Int'l Rev of Law 2013:8, https://journals.qu.edu.qa/index.php/IRL/article/view/1265, available at http://www.qscience.com/doi/pdf/10.5339/irl.2013.8.
} 
transmission of electricity across borders. ${ }^{102}$ There is a rapid expansion of infrastructure projects in new demand centres in Africa, Caucasus, Central Asia and South East Asia. The emergence of power pools and super grids presents a new opportunity for international law of energy to receive acceptance. At the international level, the WTO/GATT and ECT provisions offer an umbrella framework, and UNCLOS becomes relevant when considering undersea cables. The revised draft Energy Charter Model Agreements for Cross-Border Pipelines and Electricity Line Agreements contain new provisions ${ }^{103}$ referring to the Paris Agreement and transparency initiatives and confirms that gas pipelines are to be climate friendlier. It proposes incorporation of climate change and human rights-clauses, and foresees new methods for effective exchange of information and establishment of responsive technical standards. ${ }^{104}$

However greater integration seems only viable under technically-based, dedicated rules which are best implemented at the regional level. ${ }^{105}$ In the EU, these are produced through the European Network of Transmission System Operators for Electricity (ENTSO-E) and the Agency for Cooperation of Energy Regulators (ACER). Other regional frameworks are re-aligning with the more established EU regulatory regime to meet climate change goals. This regime for regional system operability and infrastructure networks with or without storage solutions - in the absence of an international authority/legal framework - is the most evolved regional framework and is becoming an international best practice and influencing regulatory evolution elsewhere. Conceptually, this EU law could be considered to form international law of energy by way of an institutional dissemination.

This re-alignment extends to disposing of the generation infrastructure of the past, the so-called decommissioning aspects of oil platforms. There is lack of an international law because the initial understanding was that all installations would simply be removed in total. In Europe, the majority of offshore oil and gas installations are located in the North Sea and the Protection of the Marine Environment of the North-East Atlantic (OSPAR) Decision 98/3 ${ }^{106}$ requires full removal of most offshore installations from the marine environment at the end of their useful life. It also encourages reuse and recycling of these installations. However, reports of possible damage to new marine life have initiated discussion of alternative methods of decommissioning, driving the development of

102 The recast Electricity Directives and the recast Electricity Regulation, parts of the so-called Clean Energy Package for all Europeans proposed by the commission in November 2017, were adopted in May 2019. They can be considered as a fourth electricity market package.

${ }^{103}$ The 2008 Model Agreements are available at: https://energycharter.org/what-we-do/trade-and-transit/modelagreements/.

${ }^{104}$ Dr Gokce Mete has been in the Legal Advisory Task Force (LATF) of the Energy Charter Secretariat prior to joining the Secretariat full time in February 2019. The knowledge shared here is based on her involvement in her LATF capacity.

${ }^{105}$ Many Latin American states, particularly Brazil, and India are looking to copy-paste EU law for transmission. In the immediate neighbourhood of the EU, Balkan states - most of whom are an EU candidate, and Ukraine are already implementing the EU energy laws despite not being an EU member state. Georgia recently joined the Energy Community Treaty for this purpose.

${ }^{106}$ OSPAR Decision 98/3 on the Disposal of Disused Offshore Installations, OSPAR Commission, List of Decisions, Recommendations and Other Agreements Applicable within the Framework of the OSPAR Convention - Update 2018. 
specific international rules. ${ }^{107}$ The 1989 International Maritime Organisation (IMO) Guidelines and Standards for the Removal of Offshore Installations and Structures on the Continental Shelf and in the Exclusive Economic Zone allowed structures to be left in place on a case-by-case. The guidelines also refer to the possibility of "new use or other reasonable justification" for in situ disposal. This initiated discussion on possible conversion of obsolete oil or gas platform into a dedicated artificial reef. Rigs-to-Reefs (RTR) is the practice of converting decommissioned offshore oil and petroleum rigs into artificial reefs. ${ }^{108}$ The adoption by the EU of the so-called Clean Energy Package of legislation is driving industry using carbon-capture and storage technology (CCS). It is now considered that the most cost effective and environmentally friendly ways of treating old rig infrastructure would be not to remove it all, but rather repurpose it as part of a new CCS network. ${ }^{109}$ In December 2018, the UK regulator, the Oil and Gas Authority, awarded its first carbon dioxide (CO2) appraisal and storage licence. ${ }^{110}$

\section{Re-alignment of international law on trans-boundary energy resources}

Many natural energy resources, both fossil and renewable, are transboundary. These fall under plural branches of international law, ranging from the law of the sea to transboundary watercourses. Re-aligning itself with the meta-norm of climate action, the international law on international watercourses is developing an energy-specific governance aspect. ${ }^{111}$

Under the law of the sea, the Timor-Leste $v$ Australia conciliation of 2016 charts the path to the governance of marine energy resources that straddle jurisdictional line or are in disputed waters. ${ }^{12}$ Conciliation is a dispute settlement mechanism that has long lain dormant when compared to binding arbitration and adjudication. Under the 1982 UN Convention on the Law of the Sea, it applies, mandatorily, for maritime delimitation disputes where one of the parties has opted out of binding third-party dispute settlement. Conciliation then could simply emulate delimitation by the drawing of a line pursuant to the principles of equidistance-cum-special circumstances. It would follow a rationale of legal certainty for all marine resources, living and non-living. However, In

\footnotetext{
107 Ann Scarborough Bull \& Milton S. Love, 'Worldwide oil and gas platform decommissioning: A review of practices and reefing options', (2019) 168 Ocean \& Coastal Management 274.

${ }^{108}$ US Bureau of Safety and Environmental Enforcement's definition of rigs-to-reef is available here: https://www.bsee.gov/what-we-do/environmental-focuses/rigs-to-reefs.

109 Circular Economy Scotland, https://www.green-alliance.org.uk/circular-economy-scotland.php.

110 In addition, three of the largest ports in Europe - Rotterdam, Antwerp and Ghent - are to be used to capture and bury $10 \mathrm{~m}$ tonnes of $\mathrm{CO} 2$ emissions under the North Sea in what will be the biggest project of its kind in the world. The ports, which account for one-third of the total greenhouse gas emissions from the Belgium, Netherlands and Luxembourg region, are to be used to pipe the gas into a porous reservoir of sandstone about two miles ( $3 \mathrm{~km})$ below the seabed.

${ }^{111}$ For instance for the Volta Basin, Convention on the status of the Volta River and the Establishment of Volta Basin Authority, 19 January 2007, available at: https://iea.uoregon.edu/treaty-text/2007-voltabasinauthorityentxt; implementing the UN Convention on the Law of Non-Navigable Uses of International Watercourses, Adopted by the General Assembly of the United Nations on 21 May 1997, resolution 51/229, annex, Official Records of the General Assembly, Fifty-first Session, Supplement No. 49 (A/51/49), entered into force 17 August 2014.

112 PCA Case No 2016-10, In the Matter of the Maritime Boundary between Timor-Leste and Australia (The Democratic Republic of Timor-Leste - and - The Commonwealth of Australia), Report and Recommendations of the Compulsory Conciliation Commission between Timor-Leste and Australia on the Timor Sea, 9 May 2018.
} 
Timor-Leste $v$ Australia, the conciliation commission engaged in structured dialogue with the parties that led to a classic maritime boundary treaty in the Timor Sea and to the creation of a special regime for the joint exploitation of the Greater Sunrise Field. The general implication is that conciliation, whether mandatory or voluntary, permits the negotiation of regimes enabling the socially optimal exploitation of a trans-boundary energy resource, by an agency making decisions on energy projects based on merit-order and to reduce externalities, including their carbon emissions. ${ }^{113}$

\section{Conclusions}

International law has rapidly moved beyond the principle of permanent sovereignty. This paper clarifies how international lawyers now ought to think about international law relating to energy. It suggests substituting a thicker, evaluative concept - the international law of energy - for a thinner international law on energy. The international law of energy is centred on the specific metanorm that has evolved since 2015 by SDG 7 and 13 and the Paris Agreement objectives and formalises the transition to a global energy system that delivers sustainable and affordable energy to all. The meta-norm creates the impetus for a change in the regulatory approaches and international rules on the global energy value cycle (for instance the modernisation of the ECT), and for a re-alignment of the extant, plural international law that also apply on energy. The metanorm determines the boundaries of what does and what does not belong to the international law of energy. Mainly because a new meta-norm emerged with will of all countries engaged in the making of SDG \& Paris - and lawyers can talk about international law on energy, because the meta norm is so substantive and influential that it continuously evolves and it challenges other branches of international law that applies to energy by creating this realignment that draws these energy related issues from other branches to its very own branch as it evolves - like a magnet it brings them all to a whole under international law of energy - and this results in energy specific principles to emerge, such as a right to clean energy, technology transfer and right to regulate. The conclusion is that the international law of energy is a distinct subject-matter of public international law.

It is important for international lawyers to understand this newly defined concept, inter alia, for assessing cases, investment decisions, new rules when negotiating treaties, when granting new licences for cross-border projects and when signing new trade agreements. It is specific, and it has a specific impact on regulated energy related trade, investment and business activity as well as on social justice and welfare. It carved out its own sphere though interrelated with other disciplines, and it should be interpreted as such.

Analysts will consider the position of this international law of energy with the rest of international law. It is also for specialists to assess that the international law of energy, remains an integral part of public international law, innovates and contributes to models that may be emulated elsewhere.

\footnotetext{
${ }^{113}$ Further Volker Roeben \& Rafael Macatangay, 'Conciliation for marine transboundary energy resources. A law and economics approach', in Keyuan Zhou (ed) The 21st Century Maritime Silk Road: Challenges and Opportunities for Asia and Europe (in print).
} 
Some examples have been touched upon over the course of this paper. These include the slip in the treaty paradigm, spontaneous order for trans-boundary social welfare maximisation, the management of policy exit by states, and corporate responsibility.

Through it, the international community of states delivers strategic change on an existential challenge for all its members. This political community receives the indispensable instrument to bring about a transformation of the global energy system that is universally binding, and hence effective, and that complies with the formal rationality of law. In turn, the international law of energy is an empirical verification of the international community of states as an actor. 